\title{
Využití odpadního tepla k úpravě odpadních vod z průmyslových procesů
}

MAREK VONDRA, PETR BOBÁK, VÍTĚZSLAV MÁŠA

Klíčová slova: odpadní voda - odpadní teplo - průmysl - odpařování - zahuštování - vícestupňová mžiková destilace

\section{SOUHRN}

Článek se zabývá zahuštováním odpadních vod s využitím odpadního tepla z přidružených průmyslových procesů. $V$ České republice je ročně průmyslem vyprodukováno více než 280 mil. m³ odpadní vody a ještě větší množství vody průmysl spotřebuje. Zároveň je toto odvětví výrazným konzumentem energetických zdrojů, které však zpravidla nejsou důsledně využity. Ročně z průmyslu odchází více než 17,5 TWh odpadního tepla. Jedním z řešení, které má potenciál k redukci odpadních vod při současném využití přebytečného tepla, je odpařování odpadních vod. Za tímto účelem je možné uvažovat o uplatnění osvědčených technologií použivaných při odsolování mořské vody (MED, MSF), jejichž základní provozní parametry jsou $v$ textu popsány. Z mnoha výhod těchto zařízení lze jmenovat jednoduchou konstrukci, spolehlivý chod a ekonomiku provozu výrazně podpořenou dostupným odpadním teplem. Při zamyšlení nad konkrétními možnostmi aplikace uvedených metod Ize vycházet z četných studií, které se zabývaly odpařováním vody ze širokého spektra odpadních vod. Předkládaný text prezentuje výsledky ze zahuštování vod z kovodělného, koksárenského a farmaceutického průmyslu či z provozů na zpracování biomasy. Potenciál k úpravě odpadních vod zahuštováním v České republice je pak součástí úvah a výpočtů v poslední části textu. Z výsledků plyne, že při využití pouhého zlomku (0,94\%) průmyslového odpadního tepla Ize odpařováním ušetřit až 8,5 mil. m³ $^{3}$ vody ročně. Možnosti zkoumaného prístupu jsou tedy obrovské.

\section{ÚVOD}

Ochrana životního prostředí a snižování spotřeby prírodních zdrojů jsou $v$ dnešní době všudypř́tomnými požadavky národních i mezinárodních politik a dokumentů. Tento trend má přispět $k$ udržitelnému rozvoji společnosti a zajištění odpovídajících životních podmínek pro současné i budoucí generace. Organizace spojených národů představila ve svém strategickém dokumentu [1] společné cíle v oblasti udržitelného rozvoje po roce 2015. Patří mezi ně snaha zefektivnit hospodaření s vodními a energetickými zdroji tak, aby byly všeobecně dostupné a nedocházelo k jejich zbytečnému plýtvání. Tyto priority vycházejí z odhadů, podle kterých více než miliarda světové populace trpí nedostatkem vody a pro další stamiliony je znečištěná voda příčinou zdravotních problémů [2]. Nedostatek dostupných energetických zdrojů pak může být jedním z důvodů, proč více než 80 \% světově použité vody není před vypuštěním žádným způsobem upravováno [3].

\section{PRŮMYSLOVÉ ODPADNÍ VODY}

Na úrovni Evropské unie je vodohospodářská politika harmonizována směrnicí 2000/60/ES, jejímiž prioritami jsou mimo jiné snižování objemu odpadních vod a množství znečištujících látek vypouštěných do vod či zajištění dostatečných vodních zásob pro období sucha [4]. V České republice jsou tyto požadavky promítnuty do príslušných právních předpisů a dlouhodobých koncepcí, např. $[5,6]$. Přestože je $v$ ČR dlouhodobě monitorován pokles odběrů vody a zvyšování podílu čištěných odpadních vod, zasluhuje si tato problematika zvýšenou pozornost. Podle údajů MŽP bylo v roce 2013 odebráno celkem 1649,8 mil. m³ vody, přičemž mezi hlavní odběratele patřila energetika (43,2\%), vodovody pro veřejnou potřebu (37,5 \%) a průmysl (15,1\%) [7]. V evropských statistikách jsou energetika a průmysl zodpovědné za odběr přibližně $40 \%$ veškeré vody [8]. V některých zemích (např. Německo, Nizozemí, Mad’arsko) toto číslo přesahuje hranici $80 \%$ [9]. Oba sektory jsou zároveň významnými znečištovateli vody. Podle zdroje [8] je pouze 60 \% odpadní vody z energetiky a průmyslu před vypuštěním upravováno. Nutno ovšem podotknout, že velkou část této odpadní vody tvoří chladicí voda pro účely výroby elektřiny, jejímž dominantním znečištujuícím prvkem je zvýšená teplota. V ČR je zastoupení hlavních emitentů odpadní vody srovnatelné s odběrateli. Konkrétní čísla Ize nalézt ve zdroji [7]. Množství vody vypouštěné z energetických závodů kolísá v závislosti na aktuálně připojených provozech a v roce 2013 představovalo 31,9\% všech odpadních vod. Průmyslové odpadní vody bylo ve stejném období registrováno 282,4 mil. m³, tedy zhruba 15,3\% z celku. Hlavními sektorovými znečištovateli jsou chemický, papírenský, těžební a potravinášský průmysl. Tato odvětví zatěžují vodní zdroje zejména organickými látkami a těžkými kovy. Objemově méně významným (0,4\% odpadních vod), ale presto výrazným emitentem znečištujících látek je zemědělství. Hlavním problémem tohoto odvětví není vypouštění z bodových zdrojů, ale vliv zemědělské činnosti na tzv. plošné znečištění, které se do povrchových a podzemních vod dostává splachem hnojiv a pesticidů ze zemědělské půdy. Obecně Ize konstatovat, že jakost vody ve vodních tocích se $v$ posledních dvaceti letech výrazně zvýšila. Přesto existují oblasti, kde redukce znečištění bude v prrištích letech prioritou [10]. Konkrétní problémy jednotlivých povodí jsou mapovány Ministerstvem zemědělství v rámci přislušných prípravných dokumentů [11].

\section{ODPADNÍ TEPLO Z PRŮMYSLU A JEHO VYUŽITÍ}

Snaha o účinnější využívání primárních energetických zdrojů, která by měla omezit závislost Evropy na jejich importu a přispět ke snižení ekologické zátěže, se projevuje $v$ řadě evropských dokumentů a směrnic. V rámci strategie Evropa 2020 a prijiatého Energetického balíčku 20-20-20 se Evropská unie zavázala k redukci 
emisí oxidu uhličitého o 20 \% (oproti úrovni v roce 1990), poklesu spotřeby primárních energetických zdrojů o 20 \% (v porovnání s projekcemi z roku 2007) a k navýšení podílu obnovitelných zdrojů v energetickém mixu na 20 \% [12]. Všechny tři požadavky jsou úzce provázané. Spálení menšího množství primárních zdrojů znamená méně $\mathrm{CO}_{2}$ uvolněného do atmosféry, zároveň se automaticky zvedá relativní zastoupení obnovitelných zdrojů. K úsporám primárních paliv nedochází pouze zvyšováním efektivity jednotlivých technologií či nahrazováním konvenčních energetických zdrojů za obnovitelné. Výrazných úspor Ize dosáhnout integrací dílčích výrobních či zpracovatelských operací, tedy komplexním přístupem, jehož cílem je snižování energetické náročnosti procesů jako celku. Záměrem tohoto prístupu je obvykle maximální využití dostupného odpadního tepla, respektive odpadních proudů obecně. Pod pojmem odpadní teplo Ize rozumět energii obsaženou v jakémkoliv typu odpadního proudu (spaliny, chladicí voda, horký vzduch), který má teplotu převyšující teplotu okolního prostředí a jenž by za běžných podmínek odcházel z procesu bez využití. Odborná veřejnost se $\checkmark$ definicích odpadního tepla rozchází, a to zejména ve vymezení jeho teplotních rozsahů. Podle [13] Ize za vysokopotenciální odpadní teplo považovat zdroje o teplotě přesahující $500^{\circ} \mathrm{C}$, v oblasti od 150 do $500^{\circ} \mathrm{C}$ pak mluví o teple se středním energetickým potenciálem. Nejčastěji přitomným zdrojem odpadního tepla je teplo nízkopotenciální (pod $150^{\circ} \mathrm{C}$ ), které je z logiky věci součástí jakéhokoli odpadního proudu přesahujícího teplotu okolí. Přestože je zastoupení nízkopotenciálního tepla výsadní, zůstává problémem jeho účelné využití, nebot? energii o takto nízké teplotě Ize uplatnit jen v omezeném množství průmyslových procesů. Tento fakt je jedním z důvodů, proč jsou v praxi velké objemy odpadního tepla mařeny. Tím dochází nejen k tepelnému znečištění okolního prostředí, ale i k plýtvání se zdroji energie [14]. Hlavními zdroji odpadního tepla jsou kombinovaná výroba elektřiny a tepla, spalovny odpadů, energeticky náročná průmyslová odvětví (chemický a petrochemický průmysl, hutnictví železa a neželezných kovů, průmysl stavebních hmot, papírenství apod.), geotermální pole, zařízení na energetické využití biomasy a sluneční záření [15].

Průmyslová výroba je kromě vody také významným konzumentem energií. V EU se na konečné spotřebě energií podílí $25 \%$, v ČR pak téměř 1/3, což odpovídá 3217 TWh, respektive 87,6 TWh [16]. Jaké celkové množství energie odchází z průmyslových procesů ve formě odpadního tepla je však obtižné určit. Do mezinárodních statistik nejsou údaje o odpadním teple zahrnovány [15]. Podobná je situace v ČR, kde neexistuje subjekt, který by celostátní bilance tepelných energií zpracovával [17]. Dostupné jsou pouze dílčí statistiky zahrnující specifický okruh průmyslových podniků. Podle publikace [18] vydané Čsú bylo $v$ roce 2013 v rámci transformačních procesů v energetice uvolněno zhruba 7,5 PJ (2,1 TWh) chemického a odpadního tepla. Toto číslo však nepostihuje veškeré teplo v jednotlivých provozech uvolněné a týká se převážně větších technologických jednotek. Navíc jde o statistiku vycházející z výkazů omezeného okruhu podnikatelských subjektů, které jsou registrovány k výrobě elektrické energie či tepla nebo mají za tímto účelem registrovanou jednotku. Uvedená hodnota tedy nezahrnuje velké množství průmyslových provozů, které teplo v rámci své činnosti produkují, ale nejsou za tímto účelem patřičně registrovány. Částečnou informaci o využití odpadní energie v průmyslových procesech nabízí analytický materiál MPO [19]. Podle tohoto dokumentu byly v rámci dotačních programů mezi roky 2007-2013 v průmyslových procesech upotřebeny téměř 2 PJ (0,66 TWh) odpadního tepla. Uvedená hodnota sice neodhaluje celý potenciál odpadního tepla v průmyslu, ale naznačuje, že dosažení výrazných úspor je v tomto směru reálné. Studie [15], jejímž cílem bylo mimo jiné podrobně zmapovat nejvýznamnější zdroje tepla v EU za účelem dalšího plánování v oblasti teplárenství, predpokládá minimálně 64 PJ (17,8 TWh) odpadního tepla dostupného z průmyslových procesů $v$ ČR. V měřítku celé EU se pak jedná o číslo 10287 PJ (2857,5 TWh). Zmíněné hodnoty odpovídají odhadům uvedeným ve zprávě [20], podle které 20 až 50 \% vstupní energie odchází z průmyslových procesů nevyužito. Vezmeme-li v potaz dolní hranici $20 \%$ a vztáhneme-li tento údaj na průmyslem v ČR ročně spotřebovaných 87,6 TWh, dostaneme hodnotu 17,5 TWh, která je v souladu se studií [15]. Volbu dolní procentní hranice ospravedlňuje fakt, že studie [15] zahrnuje pouze velké tepelné zdroje.

\section{ODPAŘOVÁNÍ ODPADNÍCH VOD}

Z uvedených faktů je zrejmé, že odpadního tepla odchází z průmyslových procesů velké množství. Zásadní otázkou zůstává, jakým způsobem ho využít. Při hledání vhodného řešení je třeba brát $v$ úvahu skutečnost, že většinu

Tabulka 1. Výhody a nevýhody odpařování prưmyslových odpadních vod

Table 1. The pros and cons of evaporation technologies for industrial wastewater treatment

\section{Výhody}

Výrazné snížení objemu odpadních vod

Možnost využití odpadního (i nízkopotenciálního) tepla, a tím dosažení relativně nízké energetické náročnosti

Jednoduché a spolehlivé technologické procesy

Využívané odpadní proudy (teplo a voda) jsou zpravidla dostupné na jednom místě, prípadně tvoří jeden a týž proud

\section{Nevýhody}

Dodatečné investiční a provozní náklady pro provozovatele

Dodatečné prostorové nároky

V prípadě nevyhovující kvality produktů nutnost doplnění o další technologie

Náklady na podpůrné chemické látky (snižování pH, ionizace, redukce pěnění)

Odpařená voda je dostupná přímo v provozu a může být okamžitě

k dispozici

Dostatečně zahuštěný koncentrát může být recyklován nebo využit

k výrobě energií jako palivo

Modulární charakter odpařovacích technologií umožňující jejich

prestavbu či přemístění

Kontinuální i vsádkový provoz

Zahuštění koncentrátu může být regulováno 
odpadního tepla predstavuje teplo nízkopotenciální, tedy do $150^{\circ} \mathrm{C}$. Podle autorů textu má vysoký potenciál využití odpadního tepla k odpařování (zahuštování) průmyslových odpadních vod. Ačkoliv je proces odpařování notoricky známým jevem, který nalézá uplatnění v širokém spektru lidské činnosti, jeví se jeho využití v kontextu současných okolností a environmentálních požadavků jako dostatečně zajímavá možnost, která by neměla být přehlížena. Odpařování odpadních vod s využitím přebytečného odpadního tepla mưže být jedním ze způsobů, jak naplnit závazky ČR ke snižování objemu odpadních vod a dosažení úspory 191,8 PJ primárních energetických zdrojů mezi lety 2014 a 2020 [19].

Aplikace odpařování na úpravu odpadních vod se může ve světle moderních a progresivních technologií jevit jako krok zpět. Při hlubším zamyšlení se však nabízí řada výhod, které mohou z odpařování učinit zajímavé řešení mnoha problémů. Přehled kladů a záporů nabízí tabulka 1.

Hlavní devízou odpařování je schopnost vytěžit maximum z odpadních proudů, které by jinak zůstaly nevyužity. Teoreticky je tímto způsobem možné nejen snižit objem odpadního tepla a vod odcházejících z průmyslové výroby, ale zároveň se nabízí príležitost zpětného využití získaných produktů - vody (destilátu) a látek zahuštěných v koncentrátu (schematicky na obr. 1). Využitelnost těchto zdrojů bude samozrejmě závislá na jejich vlastnostech a charakteru daného průmyslového procesu. Nelze proto vyloučit potřebu dodatečné úpravy produktů před jejich recyklací (např. sušením). Zajímavou alternativou je možnost energetického využití koncentrátu jeho spalováním. Ekonomická smysluplnost takového řešení bude vázána na dostupnost vhodného spalovacího zařízení, výhřevnost obsažených látek a na zbytkovou vlhkost koncentrátu.

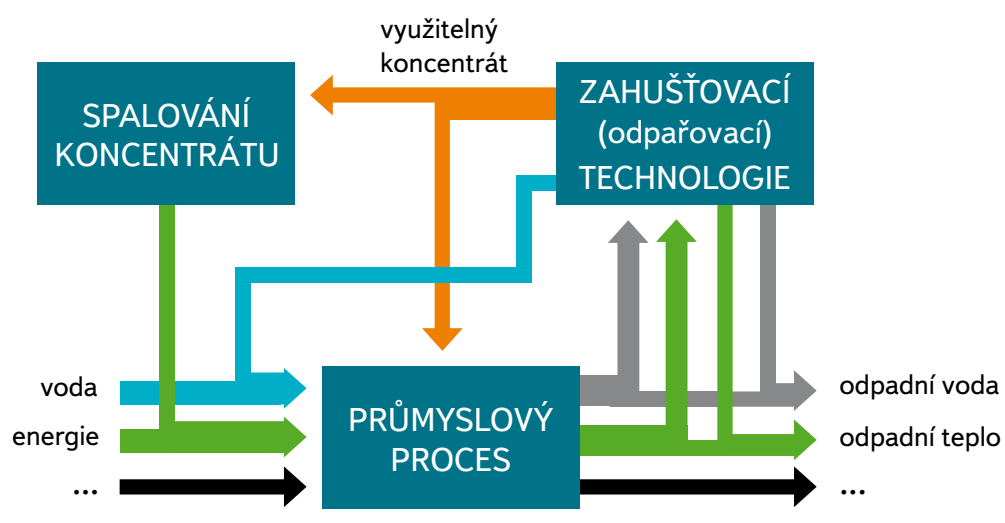

Obr. 1. Zjednodušené schéma hlavních toků spojených se zahuštováním odpadních vod Fig. 1. Simplified flow diagram of the main process streams connected to wastewater thickening

\section{ODPAŘOVACÍ TECHNOLOGIE}

Proces odpařování se využívá v celé řadě aplikací. V zařízeních zvaných odparky dochází k odlučování nejtěkavější složky z roztoku, suspenze nebo emulze. Tímto způsobem se bud'to získává nejtěkavější složka směsi (nejčastěji voda), nebo je cílem zahuštění roztoku. Odparky mohou být jedno- či vícečlenné, s cirkulací směsi nebo bez, pracující za atmosférických podmínek i za sníženého tlaku, s kontinuálním nebo vsádkovým provozem. Používají se např. k zahuštování mléka, ovocných štáv nebo k výrobě koncentrovaných kapalných hnojiv [21]. Nejrozšířenější aplikací odparek je však odsolování mořské vody.

Odsolování slaných vod je oborem, jenž neustále nabývá na významu. $\checkmark$ roce 2013 překročila celosvětově instalovaná kapacita odsolovacích jednotek hranici 80 mil. $\mathrm{m}^{3}$ čerstvé vody za den [22]. Přestože vůbec nejrozšířenější technologií je v současnosti reverzní osmóza, zaujímají tepelné metody (využívající principu odpařování) v odsolovacím průmyslu nezastupitelnou roli. Patří mezi ně vícestupňová mžiková destilace (MSF), vícestupňové odpařování (MED) a komprese páry (VCD). Posledně jmenovaná technologie však není schopná efektivního využití odpadního tepla, proto jí dále nebude věnována pozornost. MSF a MED jsou dlouhodobě osvědčenými metodami, které jsou využívány zejména k vysokokapacitnímu odsolování (desítky tisíc $\mathrm{m}^{3}$ vyprodukované vody denně) slaných a brakických vod. Právě dlouhodobé provozní zkušenosti s vysoce agresivní slanou vodou dělají z těchto technologií vážné kandidáty na odpařování mnoha typů odpadních vod.

\section{Vícestupňové destilace}

Technologie MED (Multi-effect distillation) je považována za termodynamicky vysoce efektivní. MED jednotka se obvykle skládá z několika stupňů (komor), ve kterých je postupně snižován tlak, a tím i bod varu. Slaná napájecí voda je ohřivána vodní parou vně nebo uvnitř kondenzačního potrubí, které prochází skrze komoru. Voda odpařená v jednom stupni je zdrojem tepla (páry) pro stupeň následující. Počet stupňủ se volí s ohledem na dostupný teplotní spád a minimální prípustnou teplotní diferenci mezi sousedními komorami. Vstupní teplota napájecí vody se běžně pohybuje kolem $70^{\circ} \mathrm{C}$, čímž se technologie chrání před korozí [23]. Energetická náročnost metody se pohybuje kolem 3,8 kWh a 16,4kWh na $\mathrm{m}^{3}$ destilované vody [24]. Př́klad vícestupňové MED technologie je na obr. 2.

\section{Vícestupňová mžiková destilace}

Také technologie MSF (Multi-stage flash distillation) je vysoce náročná na spotrebu tepelné energie a pracuje $v$ několika stupních (obvykle více než 20) s postupně klesajícím tlakem (až 0,07 bar). Zpravidla nasycenou párou předehřátá slaná voda vstupuje do odpařovací komory. Zde dochází k prudkému mžikovému odpaření (tzv. flash) vlivem nerovnováhy mezi teplotou slané vody a rovnovážnou teplotou, která odpovídá podtlaku v komoře. Odpařená voda je přes odlučovače kapek (demistery) odváděna na teplosměnnou plochu, kde zkondenzuje a předá výparné teplo slané vodě, která nově vstupuje do procesu. Destilát je odváděn pryč z komory, zkoncentrovaná slaná voda postupuje do dalšího stupně. $\checkmark$ konvenčních velkokapacitních závodech se teplota vstupní slané vody pohybuje od 90 do $120^{\circ} \mathrm{C}$, výstupní potom kolem $30^{\circ} \mathrm{C}$ v závislosti na ročním období a teplotě okolí [26]. S vyšší teplotou roste výtěžnost technologie, ale zároveň s ní i míra usazování a koroze. Energetická náročnost procesu se uvádí kolem 5,2kWh a 19,4 kWh $\mathrm{k}_{\mathrm{t}}$ na $\mathrm{m}^{3}$ destilované vody. Hlavními výhodami jsou jednoduchá konstrukce a provozní spolehlivost, vysoká kvalita destilátu a nízké nároky na předúpravu vstupní vody. Nevýhodami jsou problémy s korozí a vysoká spotřeba energií [23]. Jedná se v podstatě o tytéž přednosti a slabiny jako u metody MED. Přiklad uspořádání MSF jednotky s recirkulací koncentrátu je na obr. 3.

\section{Využitelnost odsolovacích technologií}

Obě predstavené technologie disponují schopností zahuštovat vstupující procesní kapalinu a z odpařené vody produkovat destilát o určité kvalitě. Jakost destilátu se bude samozřejmě lišit v závislosti na zvolených provozních podmínkách a složení napájecí vody, zejména na zastoupení těkavých látek, které se budou odpařovat při stejné či nižší teplotě než voda. Výhodou uvedených metod je kontinuální provoz a možnost pracovat při nízkých teplotách. Pakliže by se $k$ jejich provozu využilo odpadní teplo z průmyslových procesů, jež je k dispozici de facto zadarmo, snížila by se výrazně energetická náročnost procesu, která je největší nevýhodou obou technologií. 


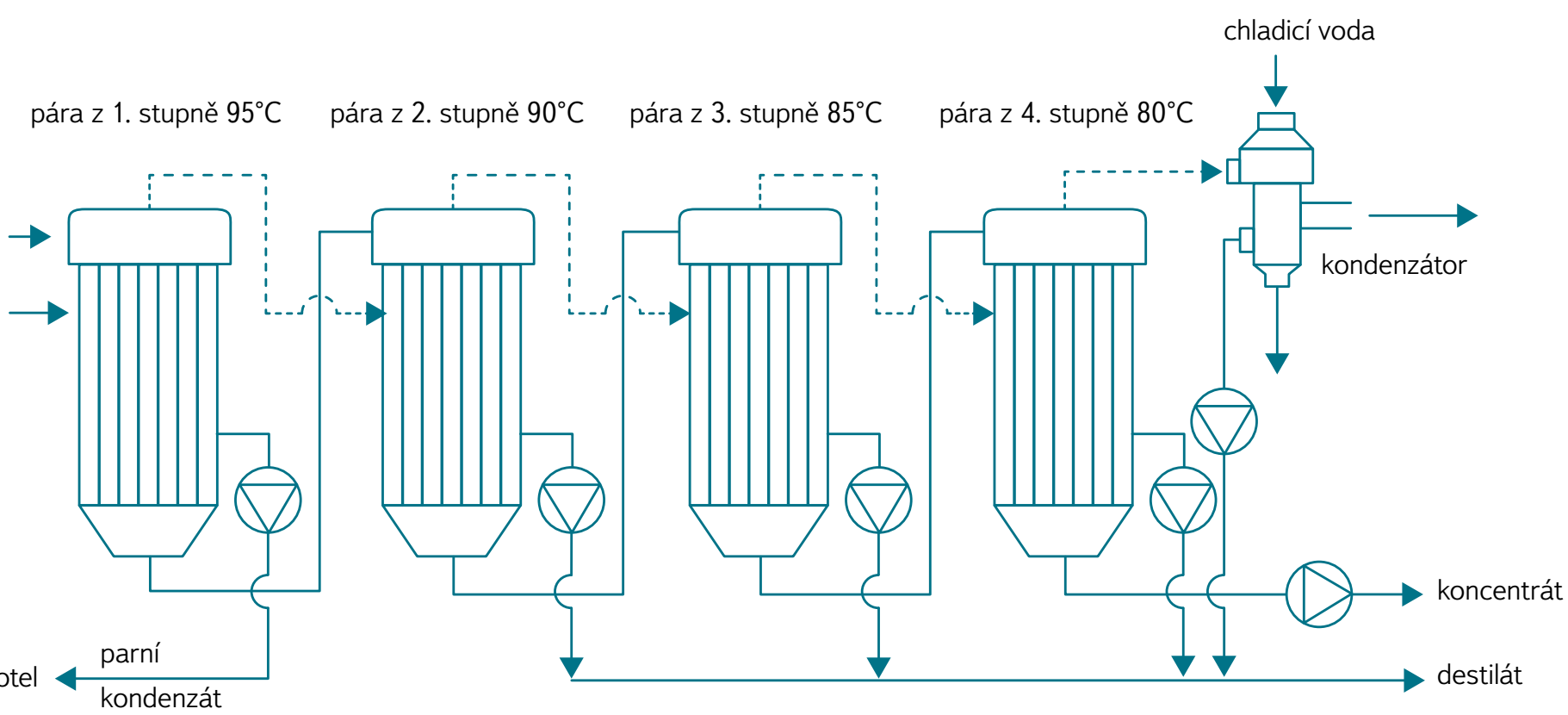

Obr. 2. Schéma 4stupňové MED technologie [25]

Fig. 2. Schematics of the MED technology with 4 evaporating chambers [25]

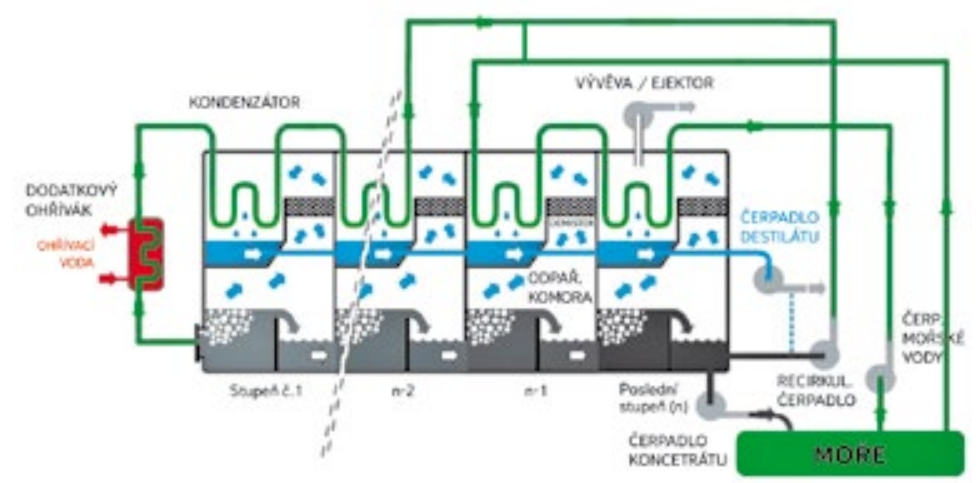

Obr. 3. Schéma MSF jednotky s recirkulací a předehřevem vstupní kapaliny [27] Fig. 3. Schematics of the MSF technology with brine recirculation and preheater [27]

Kritickou hodnotou, jež bude omezena konstrukčním řešením odsolovacích zařizení, je stupeň zahuštění výstupního koncentrátu. S rostoucím obsahem sušiny ve zpracovávané odpadní vodě se zhoršují tokové vlastnosti kapaliny, zvyšuji se požadavky na odolnost a výkon použitých čerpadel a prohlubuje se riziko sedimentace či dokonce ucpání celé technologie. Za nepumpovatelný se z tohoto pohledu označuje koncentrát s obsahem sušiny 16 \% obj. a více [28]. Teoreticky je možné spekulovat o vhodné úpravě technologií a zapojení jiných typů čerpadel (pístová, plunžrová), která jsou schopná přečerpávat suspenze až s 40\% koncentrací sušiny. Prakticky a ekonomicky však bude pravděpodobně lepší zapojení jiného typu odparek (např. vsádkové s míchadlem), mechanických separátorů (odstředivky, lisy) nebo sušáren (pro vyšší koncentrace). Teoretická výtěžnost vody odpařováním v závislosti na obsahu sušiny a hydraulických vlastnostech použité technologie je znázorněna na obr. 4. Omezení technologií z pohledu koncentrace sušiny vycházejí ze zkušeností autorů s kontinuálním odpařováním odpadních vod (8\%), z teoretické hranice pumpovatelnosti běžnými odstředivými čerpadly (16\%), z provozních možností objemových čerpadel (30 \%) a z ideálního stavu, který nezohledňuje limity dostupných technologií (bez omezení). Z grafu je mimo jiné zřejmé, že odpadní vody s minimálním obsahem sušiny mohou být zahuštovány s výrazně vyšší výtěžností. Dále je patrné, že zahuštování odpadních vod s vyšším obsahem sušiny bude spíše než recyklací vody motivováno požadavkem na redukci objemu nebo zbytkové vlhkosti. Volba vhodné výstupní koncentrace znečištujících látek by však neměla být ovlivněna pouze množstvím získané vody a objemem koncentrátu. $V$ potaz je třeba brát i výslednou kvalitu destilátu, která se s rostoucí koncentrací některých látek v odpadní vodě může zhoršovat.

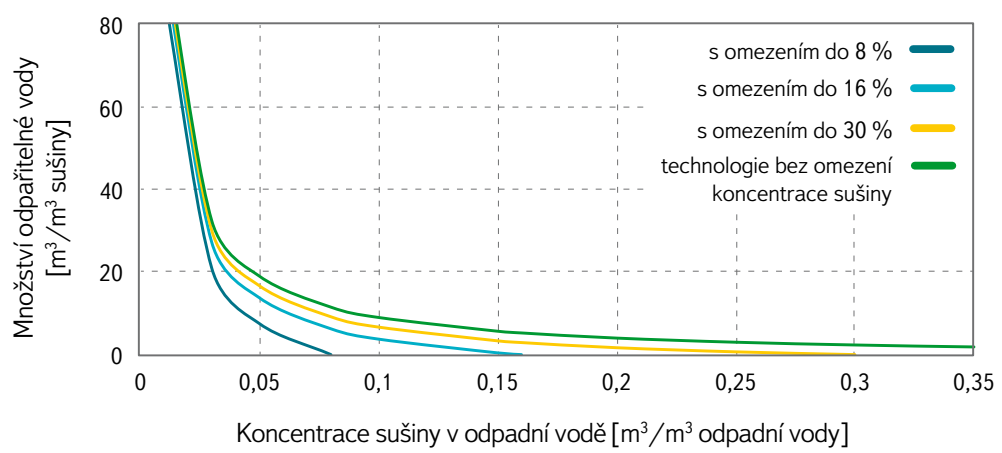

Obr. 4. Teoretická výtěžnost vody odpařováním v závislosti na obsahu sušiny v odpadní vodě Fig. 4. Theoretical distillate yield as a function of a total solids content

Pro další úvahy nad využitím odsolovacího zařízení pro zahuštování odpadních vod byla zvolena technologie MSF. Důvodem je zejména fakt, že zařízení MED jsou konstrukčně složitější a náročnější na použité materiály. Při provozu s odpadní vodou se Ize navíc obávat zanášení kondenzačního potrubí, jež je s odpařovanou kapalinou v neustálém kontaktu. Metoda MSF dostala přednost také proto, že je v současné době předmětem výzkumu na Fakultě strojního inženýrství Vysokého učení technického v Brně. Zkušenosti získané s provozem experimentální MSF jednotky se slanou i odpadní vodou tak mohou být promítnuty do dalších úvah. 


\section{MOŽNOSTI APLIKACE}

Základním kritériem využitelnosti odpařování k zahuštování procesních vod je kvalita jeho produktů - destilátu a koncentrátu. Těžko Ize předjímat požadavky konkrétních provozovatelů na jakost výstupních proudů a předkládat v tomto směru nějaká zásadní hodnocení. Některé průmyslové podniky mohou mít zájem na zpětném využití v koncentrátu obsažených látek či na jeho spalování, v takovém prípadě bude hlavním cílem důkladné odvodnění koncentrátu a nebudou sledovány zákonné limity znečištění, jak by tomu bylo při vypouštění do kanalizace nebo povrchových vod. Podobně rozdílné požadavky budou souviset s jakostí destilátu. Pokud bude záměrem provozovatele pouhé zahuštění odpadních vod a získaná voda bude vypouštěna mimo průmyslový závod, bude pravděpodobně nutné dodržení stanovených limitů. Naopak zpětné využití destilátu v technologii s nízkými nároky na kvalitu vody bude znamenat snížení požadavků na separační schopnosti odpařovacího zařízení. Přes uvedené je zřejmé, že odpařování nelze použít pro úpravu jakékoliv odpadní vody. Následující príiklady provedených experimentů nicméně naznačují, že jeho uplatnění může být vskutku široké. V představených studiích byly sledovány nejen úspěchy se separací konkrétních látek, ale i charakter využitých odpařovacích technologií.

\section{Kovodělný průmys|}

Autoři studie [29] se zabývali zahuštováním procesních vod z kovodělného průmyslu, který je výrazným producentem odpadní vody a při výrobě spotřebovává velké množství emulzí pro lubrikační a chladicí účely. Populární je v poslední době využívání tzv. vodou ředitelných emulzí, které mají nízký obsah oleje. Odstraňování oleje z těchto typů vod klasickými mechanickými metodami (usazování, odstřed’ování, filtrace, ultrafiltrace) je podle autorů neefektivní, nebot' emulze obsahují jen velmi malé (semisyntetické emulze) nebo vưbec žádné (syntetické emulze) kapičky oleje. Mechanické metody zároveň nezaručí nízké obsahy organických látek (CHSK) v upravené vodě. Studie dále konstatuje, že provozní vlastnosti odparek využívaných v průmyslu k zahuštování emulzí nebyly důkladně zkoumány a literatura se jim téměř nevěnuje. Přestože je odpařování v porovnání s jinými metodami energeticky náročnější, vykazuje voda získaná tímto způsobem z emulze mnohem lepší vlastnosti (nižší obsah organických látek) a možnosti jejího zpětného využití jsou tak širší. Zbytkový olejový koncentrát navíc disponuje poměrně malým obsahem vody, a je tedy vhodný pro spalování a výrobu energií. Experimenty probíhající v rotační vakuové odparce laboratorních rozměrů a v prưmyslové odparce s padajícím filmem ukázaly, že vakuovým odpařováním Ize ze semisyntetických a syntetických odpadních olejových emulzí získat vodu s obsahem organických látek nižších ○ 99 \%. Zároveň se potvrdilo, že při vyšším přehřátí odpadní vody je efektivita vypařování vyšší, ale klesá kvalita získané vody.
K zahuštování vody z procesu moření mědi byla využita odparka s kompresí páry o kapacitě $350 \mathrm{~m}^{3}$ odpadní vody za den. Zpráva [30] hodnotící provedené experimenty konstatovala schopnost technologie získat až 96,7 \% vody obsažené v původním objemu při celkové energetické náročnosti 13,9 kWh na $\mathrm{m}^{3}$ kondenzátu. Denně tak bylo ušetřeno zhruba $338 \mathrm{~m}^{3}$ vody, zároveň došlo k výrazné úspoře nákladů na skladování vody odpadní. V následném procesu je ročně z koncentrátu získáváno 23900 kg mědi a 170700 kg sulfátů. Kvalitu produktů jednoho z proběhnuvších experimentů shrnuje tabulka 2.

\section{Koksárenský průmysl}

Zdroj [31] popisuje experimenty s odpařováním odpadních vod z koksáren. Testování probíhalo na laboratorní vakuové odparce. Získaný destilát byl v porovnání s výchozí odpadní vodou bez kyanidů, došlo k výraznému snížení obsahu $\mathrm{NH}_{3}-\mathrm{N}$ (z $408 \mathrm{mg} / \mathrm{L}$ na cca $5 \mathrm{mg} / \mathrm{L}$ ), pH a vodivosti (ze $17110 \mu \mathrm{S} / \mathrm{cm}$ na cca 80). Naopak zastoupení organických látek (především fenolů) se odstranit nepodařilo a místy byla jejich koncentrace větší než v koncentrátu. Ke snížení CHSK pod zákonný limit (ze 7045 mg/L na cca 50) došlo až použitím podpưrného činidla v podobě sodného louhu, který snízil volatilitu fenolu jeho přeměnou na fenolátové ionty.

\section{Farmaceutický průmysl}

Ve studii [32] popisují autoři destilaci odpadní vody z farmaceutického průmyslu. Použitou destilační kolonu laboratorních rozměrů (průměr $4 \mathrm{~cm}$, výška 1,2 m, 9 pater, vyplněná Raschigovými kroužky) sice nelze označit za odparku, principiálně však dosažené výsledky za relevantní označit Ize. Odpadní voda s vysokým obsahem organických látek (CHSK až 300000 mg/L) a halogenových organických sloučenin (AOX až 7850 ppm) byla v koloně dělena na destilát (s koncentrovaným množstvím škodlivin) a destilační zbytek, který byl o tyto těkavé látky ochuzen a hromadil se $v$ dolní části kolony. Přestože byl obsah CHSK na dně kolony snížen až o $95 \%$, nepodařlo se koncentraci dostat pod zákonný limit 1000 mg/L. Zbytkový obsah organických látek se nepodařilo dostatečně odstranit ani některou z membránových metod (ultrafiltrace, nanofiltrace, reverzní osmóza), které autoři zhodnotili jako nevhodné pro odstraňování nevolatilních organických látek. Obsah halogenových sloučenin byl touto metodou úspěšně redukován až na 8 ppm.

Tabulka 2. Shrnutí analýzy koncentrace vybraných chemických prvkü sledovaných ve studii [30] Table 2. Summary of analytical results for the chemical parameters controlled in the study [30]

\begin{tabular}{|c|c|c|c|c|c|c|c|}
\hline & $\begin{array}{l}\text { Nerozpu- } \\
\text { štěné látky }\end{array}$ & $\begin{array}{l}\text { Rozpuštěné } \\
\text { látky }\end{array}$ & pH & Měd' & Olovo & Sulfáty & Vodivost \\
\hline & $\mathrm{mg} / \mathrm{L}$ & $\mathrm{mg} / \mathrm{L}$ & - & $\mathrm{mg} / \mathrm{L}$ & $\mathrm{mg} / \mathrm{L}$ & $\mathrm{mg} / \mathrm{L}$ & $\mathrm{mS} / \mathrm{cm}$ \\
\hline Odpadní voda & 7,8 & 930 & 1,85 & 240 & 0,104 & 1450 & 5,67 \\
\hline Kondenzát & $<5,0$ & 49 & 2,0 & 3,15 & $<0,005$ & 14,25 & 0,14 \\
\hline Koncentrát & 88,0 & 35500 & $<1,0$ & 9050 & 3,4 & 55000 & $>19,9$ \\
\hline
\end{tabular}




\section{Zpracování biomasy}

S cílem redukovat odpařováním objem digestátu (odpadní vody) z bioplynových stanic, a tím snížit náklady na jeho skladování a využití v zemědělské činnosti, byly provedeny experimenty popsané ve zdroji [33]. Zahuštování probíhalo v jedno- nebo dvoustupňové vakuové odparce. Klíčovým ukazatelem byla, vedle obsahu sušiny, prítomnost dusíku podle Kjeldhala. Zákonných limitů dusíku $v$ destilátu, jež by $v$ praxi umožnily vypouštění do povrchových vod, bylo dosaženo až aplikací vhodné kyseliny. Nižší pH digestátu eliminovalo volatilní formy dusíku a umožnilo snížení jeho koncentrace až na úroveň 10 mg/kg z původních $4550 \mathrm{mg} / \mathrm{kg}$.

\section{POTENCIÁL ODPAŘOVÁNÍ V ČR}

Zmíněné studie potvrzují potenciálně širokou využitelnost odpařování v průmyslových provozech a ukazují, že se mưže často jednat o smysluplné řešení problému. Zároveň ale naznačují určité slabé stránky prístupu. Tou bude zejména neschopnost vypořádat se s některými druhy volatilních látek, především dusíkatých a organických sloučenin. Základním typem řešení bude použití chemikálie snižující těkavost kritických látek nebo dodatečná úprava destilátu.

Nyní se pokusme alespoň rámcově kvantifikovat potenciál k odpařování odpadních vod v ČR. Při konstrukci tohoto odhadu budeme vycházet z údajů o průmyslově produkované odpadní vodě, dostupném odpadním teple (17,5 TWh) a ze známých provozních charakteristik konvenčních MSF odparek. Maximální možné množství odpadních vod, které mohou být upravovány v zahuštovacích zařizeních, se rovná roční produkci odpadních vod průmyslovými procesy, tj. 282,4 mil. m³. Jde samožrejmě o čistě teoretickou hodnotu, která nebude nikdy dosažena. Vytváři nám ale určitou horní hranici využitelnosti odpadního tepla ke sledovanému účelu. Optimální specifická spotřeba tepla MSF technologie na výrobu $\mathrm{m}^{3}$ destilátu $P_{\text {dest }}^{\min }=19,4$ kWh. Uvažujeme-li běžnou účinnost odpařování $\eta_{\max }$ (poměr mezi množstvím získaného destilátu a množstvím vstupující odpadní vody) $30 \%$, pak Ize podle vztahu (1) stanovit specifickou tepelnou spotřebu $=5,82 \mathrm{kWh}$ na $\mathrm{m}^{3}$ zpracované odpadní vody. Vztáhneme-li tuto hodnotu na celkově dostupnou odpadní vodu $V_{\text {ind }}$ pak podle (2) získáme maximální množství spotřebovaného odpadního tepla $Q_{\text {wh,max }}=1,64 \mathrm{TWh}$. Dostáváme se tak $\mathrm{k}$ důležitému závěru, tedy že $\mathrm{k}$ zahuštování průmyslových odpadních vod může být ročně využito nejvíce 1,64 TWh, tj. zhruba 9,4% průmyslového odpadního tepla.

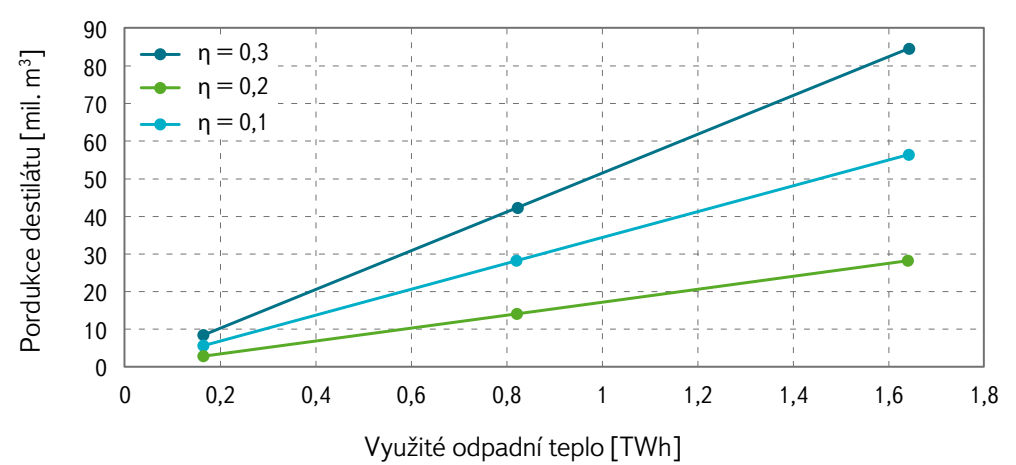

Obr. 6. Potenciální produkce destilátu v závislosti na využitém množství odpadního tepla pro různé hodnoty účinnosti odpařovací technologie (n)

Fig. 6. A potential distillate production as a function of waste heat utilized by an evaporation technology with a different level of efficiency $(\eta)$

$$
\begin{aligned}
& P_{\text {in }}^{\min }=P_{\text {dest }}^{\min } \cdot \eta_{\text {max }}\left[\mathrm{kWh} / \mathrm{m}^{3}\right] \\
& Q_{\text {wh,max }}=P_{\text {spec,th }} \cdot V_{\text {ind }}[T W h]
\end{aligned}
$$

$\checkmark$ dalším kroku se pokusme zbavit dvou zjednodušení. Za prvé je to předpoklad, že by v průmyslových provozech instalované odparky dosahovaly stejných účinností (měly stejnou specifickou spotřebu tepla) jako velkoobjemové odsolovací MSF jednotky. V praxi Ize očekávat výstavbu spíše menších MSF jednotek s nižším počtem odpařovacích komor (stupňů), a tedy s nižší účinností. Dalším zjednodušením je představa provozu zahuštovací MSF jednotky bez recirkulace. Ta bude nezbytná tam, kde bude požadováno zahuštění koncentrátu nad úroveň odpovídající jednorázovému průchodu odpadní vody technologií. Obecné schéma s recirkulací části koncentrátu je naznačeno na obr. 4. Jak účinnost, tak míra zahuštění budou individuálními parametry konkrétních zařizení. Spíše než volit konkrétní hodnoty se proto pokusíme odvodit obecné vztahy, které naznačí, jakým způsobem mohou tyto veličiny ovlivnit ekonomiku provozu odparek.

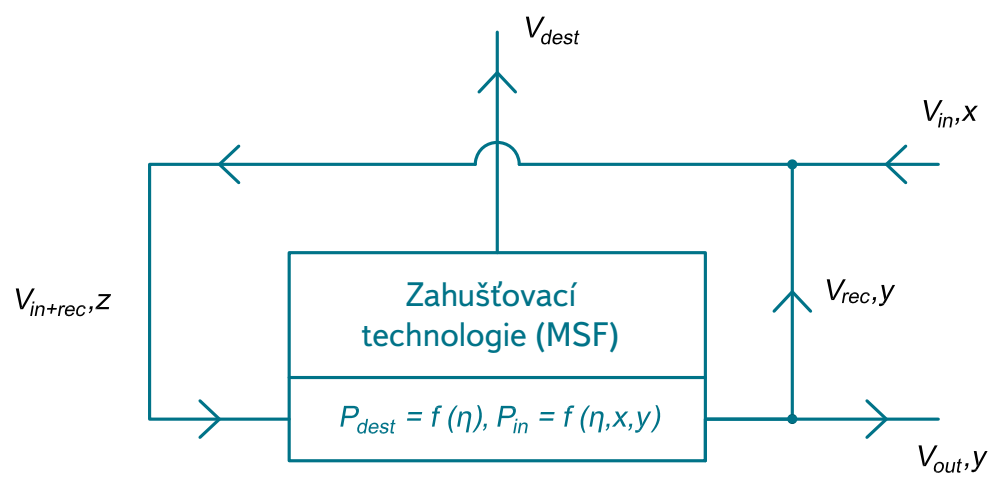

Obr. 5. Obecné schéma zapojení zahuštovací technologie s částečnou recirkulací koncentrátu

Fig. 5. General schematics of the thickening technology arrangement with a partial recirculation of the concentrate

Legenda: $V_{\text {in }}$ je objemový průtok odpadní vody; $V_{\text {dest }}$ objemový průtok destilátu; $V_{\text {in }}$ objemový průtok na vstupu do odparky; $V_{\text {rec }}$ objemový průtok v recirkulační větvi; $V_{\text {out }}$ objemový průtok koncentrátu; $x$, y a z jsou objemové koncentrace, n je účinnost odpařování technologie a $P$ značí specifickou spotřebu tepla proudu

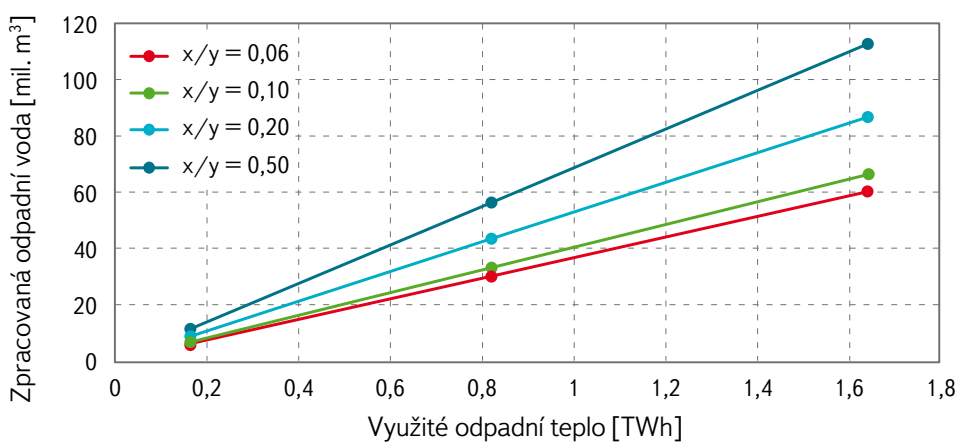

Obr. 7. Množství odpadní vody potenciálně upravitelné zahuštěním v závislosti na množství využitého odpadního tepla a zahuštovacím poměru (x/y), při 30\% účinnosti odpařovací technologie ( $\eta$ )

Fig. 7. An amount of potentially treatable wastewater by the means of evaporation as a function of waste heat utilized and a thickening ratio $(x / y)$, at the efficiency level of 0.3 
Základními parametry, které bude provozovatel volit při návrhu MSF jednotky, budou nejspíše objemový průtok zpracovaných odpadních vod $V_{\text {in }}$ objemová koncentrace sledované látky ve vstupující odpadní vodě $x$, objemová koncentrace sledované látky na výstupu y (v koncentrátu i v recirkulační větvi) a účinnost odpařování $\eta$. Nyní jsme schopni dopočítat objemový průtok koncentrátu $V_{\text {out }}$ podle (3), objemový průtok $v$ recirkulační větvi $V_{\text {rec }}$ podle (4), objemový prütok na vstupu do odparky $V_{\text {intrec }}$ podle (5), objemovou koncentraci sledované látky na vstupu do odparky $z$ podle (6) a konečně objemovou produkci destilátu $V_{\text {dest }}$ podle (7). Nárůst specifických tepelných spotřeb pak bude prímo úměrný poklesu účinnosti zařízení u $P_{\text {dest }}$ (8). Spotřebu $P_{\text {in }}$ vztaženou k objemu zpracované odpadní vody bude ovlivňovat také zahuštovací poměr (9).

$$
\begin{aligned}
& V_{\text {out }}=\frac{x}{y} \cdot V_{\text {in }}\left[\mathrm{m}^{3} / \mathrm{hod}\right] \\
& V_{\text {rec }}=\frac{V_{\text {in }} \cdot(1-\eta-x / \mathrm{y})}{\eta}\left[\mathrm{m}^{3} / \mathrm{hod}\right] \\
& V_{\text {in rec }}=V_{\text {in }}+V_{\text {rec }}\left[\mathrm{m}^{3} / \mathrm{hod}\right] \\
& Z=\frac{V_{\text {in }} \cdot x+V_{\text {rec }} \cdot y}{V_{\text {in }} \cdot \mathrm{rec}}[-] \\
& V_{\text {dest }}=V_{\text {in }+ \text { rec }} \cdot \eta\left[\mathrm{m}^{3} / \mathrm{hod}\right] \\
& P_{\text {dest }}=\frac{P_{\text {dest }}^{\min } \cdot \eta \text { max }}{\eta}\left[\mathrm{kWh} / \mathrm{m}^{3}\right] \\
& P_{\text {in }}=P_{\text {dest }} \cdot \frac{V_{\text {dest }}}{V_{\text {in }}}=P_{\text {dest }} \cdot(1-x / y)\left[\mathrm{kWh} / \mathrm{m}^{3}\right]
\end{aligned}
$$

Nyní je možné postupovat ve výpočtu opačným směrem a určit, jaké množství destilátu bude vyprodukováno a jaký objem odpadní vody bude zpracován při zadání konkrétního množství odpadního tepla $Q_{w h}$ účinnosti odpařovacího zařízení n a zahuštovacího poměru x/y. Výsledky ve vybraných bodech prezentují obr. 6 až 9. Ze zobrazených dat je zřejmé, že poměrně malý zlomek odpadního tepla z průmyslových procesů mưže přispět k úpravě a redukci značné části odpadních vod, nemluvě o zpětném využití odpařené vody ve výrobních procesech. Při využití 164 GWh, jež představují pouhých 0,94\% dostupného odpadního tepla, Ize ročně ušetřit miliony $\mathrm{m}^{3}$ vody a o toto množství zredukovat objem vypouštěných odpadních vod. Prezentovaná čísla samozřejmě nerespektují řadu reálných problémů a zahrnují spoustu zjednodušení, zejména pak to, že odpařování bude (s ohledem na kvalitu jeho produktů) vhodné k úpravě všech typů odpadních vod. Přesto Ize konstatovat, že potenciál k zahuštování odpadních vod odpařováním (s využitím MSF či jiné vhodné technologie) je v ČR obrovský a zaslouží si bližší studium.

\section{ZÁVĚR}

Cílem předložené studie nebylo hodnocení problémů spojených s odpařováním odpadních vod $v$ konkrétních průmyslových provozech, ale spíše obecné nastínění potenciálu a príležitostí, které se pro odpařovací technologie (metodu MSF) v tomto směru nabízejí. Úspěšnost a účelnost odpařování bude vždy záviset na celé řadě faktorů, zejména pak na složení odpadní vody a termofyzikálních vlastnostech jejích složek, ekonomických okolnostech konkrétního průmyslového provozu, zákonných či jiných požadavcích na kvalitu výstupů a specifických místních podmínkách. Hlavními motivy pro provozovatele nebudou jistě environmentální a společenské výhody odpařování, ale spíše ekonomické benefity. Hospodářská smysluplnost integrace odpařovacích technologií do průmyslové praxe by měla být navazujícím předmětem studia, ke kterému předkládaná práce nabízí některé podklady. Prezentované výsledky ukazují, že při využití pouhých 0,94% (164 GWh) odpadního tepla, jež vychází ročně bez využití z průmyslové výroby, může být zahuštováním upraveno až 16,9 mil. $\mathrm{m}^{3}$ odpadních vod a zpětně do procesů dodáno až 8,5 mil. $\mathrm{m}^{3}$ destilátu.

\section{Poděkování}

Tento článek vznikl v rámci projektu LO1202 za finanční podpory Ministerstva školství, mládeže a tělovýchovy v rámci Národního programu udržitelnosti l.

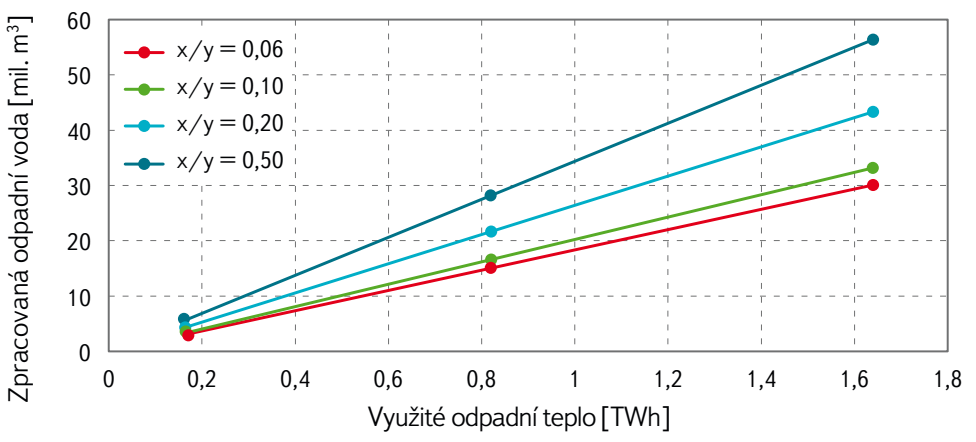

Obr. 9. Množství odpadní vody potenciálně upravitelné zahuštěním v závislosti na množství využitého odpadního tepla a zahuštovacím poměru (x/y), při 10\% účinnosti odpařovací technologie ( $\eta$ )

Fig. 9. An amount of potentially treatable wastewater by the means of evaporation as a function of waste heat utilized and a thickening ratio $(x / y)$, at the efficiency level of 0.1 


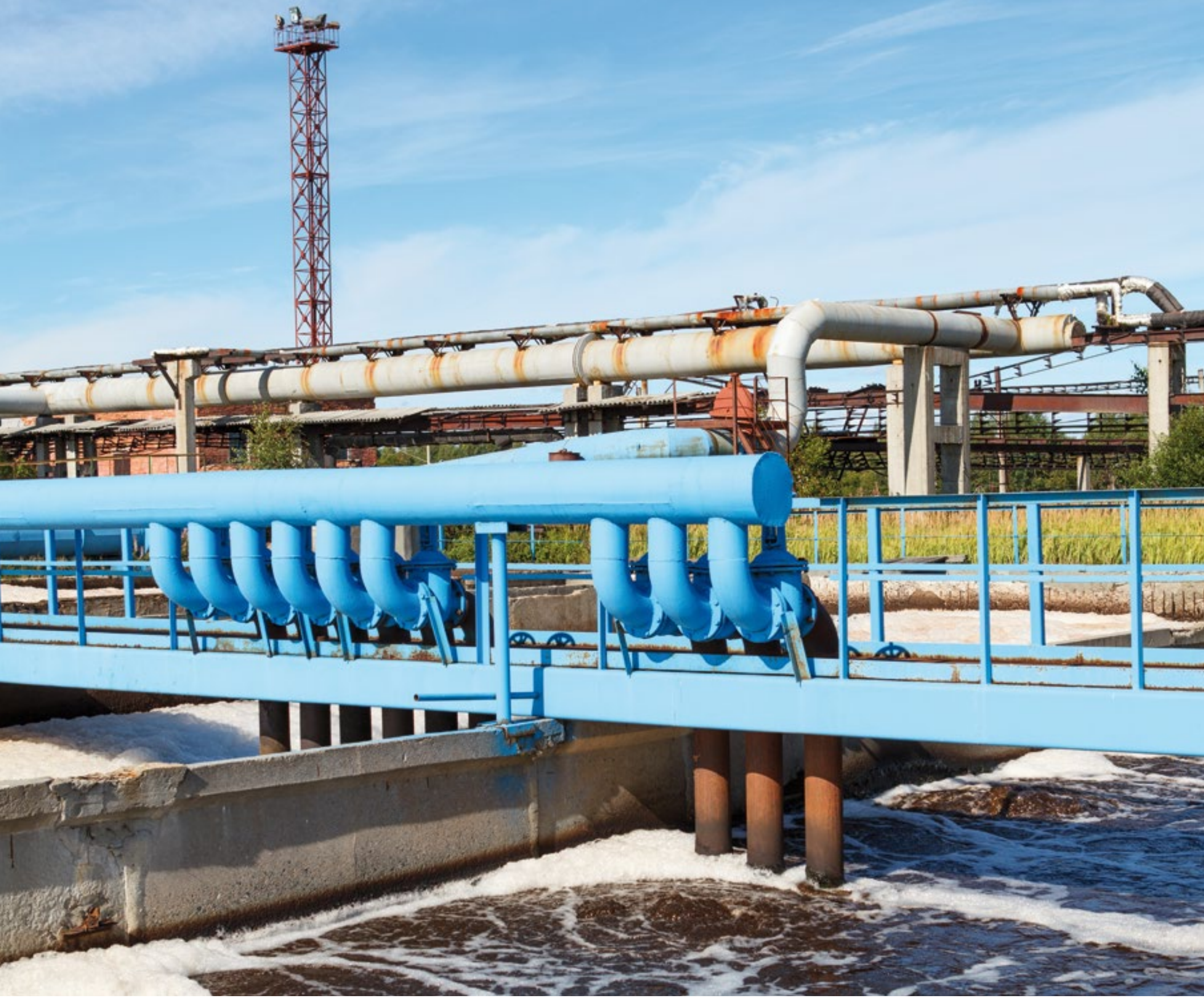

Literatura

[1] Document n: A/68/970: Report of the Open Working Group of the General Assembly on Sustainable Development Goals. United Nations. 12. srpen 2014. Dostupné z: undocs.org/A/68/970.

[2] The United Nations World Water Development Report 4: Managing Water under Uncertainty and Risk. 4. ed. Paříz: UNESCO, nedatováno. ISBN 978-92-3-104235-5.

[3] Corcoran, E. Sick Water?: The Central Role of Wastewater Management in Sustainable Development: a Rapid Response Assessment. UNEP/Earthprint, 2010. ISBN 978-82-7701-075-5.

[4] Směrnice Evropského parlamentu a Rady 2000/60/ES, kterou se stanoví rámec pro činnost Společenství voblastivodni politiky.

[5] Koncepce vodohospodárské politiky Ministerstva zemědělství do roku 2015 [online]. Ministerstvo životního prostředí, 2012, [cit. 24. září 2015]. Dostupné z: eagri.cz/public/web/mze/voda/ osveta-a-publikace/publikace-a-dokumenty/koncepce-vodohospodarske-politiky.
[6] Zákon č. 254/2001 Sb. (vodní zákon) v platném zněni.

[7] Odběry vody - vyhodnocení indikátoru. Informačni systém statistiky a reportingu. Ministerstvo životního prostředí. [online]. 17. prosinec 2014 [cit. 16. záŕí 2015]. Dostupné z: issar.cenia.cz/issar/page.php?id=1573.

[8] Förster J. Cooling for electricity production dominates water use in industry. Statistics in focus, 2014. vol. 2014, n. 14, p. 12. ISSN 2314-9647.

[9] AQUASTAT database, Food and Agriculture Organization of the United Nations (FAO). FAO [online]. 2015 [cit. 14. záŕí 2015]. Dostupné z: www.fao.org/nr/water/aquastat/data/query/index.html

[10] Jakost vody - vyhodnocení indikátoru. Informační systém statistiky a reportingu. Ministerstvo životního prostředí. [online]. 29. prosinec 2014 [cit. 24. záři 2015]. Dostupné z: issar.cenia.cz/issar/page.php?id=1579. [11] Předběžný přehled významných problémů nakládánís vodami zjištěných v části mezinárodní oblasti povodí Labe/Odry/Dunaje na území České republiky. Ministerstvo zemědělství [online]. 21. květen 2014 [cit. 24. záŕí 2015]. Dostupné z: eagri.cz/public/web/mze/voda/planovani-v-oblasti-vod/priprava-planu-povodi-pro-2-obdobi/zverejnene-informace/predbezny-prehled-vyznamnych-problemu.html. 
[12] Communication from the Comission to the European Parliament, the Council, the European Economic and Social Committee and the Committee of the Regions: Energy 2020, A strategy for competitive, sustainable and secure energy. COM(2010) 639 final. [online]. European Comission. 10. listopad 2010. Dostupné z: http://eur-lex.europa.eu/LexUriServ/LexUriServ.do?uri=COM:2010:0639:FIN:En:PDF.

[13] MA, G., J. Cai, W. Zeng, and H. Dong. Analytical Research on Waste Heat Recovery and Utilization of China's Iron \& Steel Industry. Energy Procedia [online] 2012, vol. 14, 2011 2nd International Conference on Advances in Energy Engineering (ICAEE), p. 1022-1028. ISSN 1876-6102. Dostupné z: doi:10.1016/j. egypro.2011. 12. 1049

[14] Wang, D., X. Ling, H. Peng, L. Liu, and L. Tao. Efficiency and optimal performance evaluation of organic Rankine cycle for low grade waste heat power generation. Energy [online]. 2013, vol. 50, p. 343-352. ISSN 0360-5442. Dostupné z: doi:10.1016/j.energy.2012. 11. 010.

[15] Connolly, D., B. Vad Mathiesen, P. A. Østergaard, B. Møller, S. Nielsen, H. Lund, D. Trier, U. Persson, S. Werner, J. Grözinger, T. Boermans, and M. Bosquet. Heat roadmap Europe 2050. Second pre-study for EU27 [online]. Euroheat \& Power. 27. květen 2013. Dostupné z: www.euroheat.org/Downloads-167.aspx.

[16] Final energy consumption by sector. Eurostat [online]. 2013, [cit. 24. zárí 2015]. Dostupnéz: http://ec.europa. eu/eurostat/tgm/refreshTableAction.do?tab=table\&plugin=1\&pcode=tsdpc320\&language=en .

[17] Metodické vysvětlivky (náplně ukazatelů) ke zpracování ročního statistického výkazu EP 10-01 [online]. Český statistický úřad. 30. záŕí 2014. Dostupné z: www.czso.cz/documents/10180/20556761/15015214 m. pdf/b3ccffa5-adcb-4f8c-814a-665ce3c9f392?version=1. 0 .

[18] Transformační procesy v energetice - 2013. Českýstatistický úřad [online]. 30. záŕí 2014. Dostupné z: www.czso.cz/csu/czso/transformacni-procesy-v-energetice-2013-yjsnu736td.

[19] Doplňujici analytický materiál knávrhu aktualizace Státni energetické koncepce [online]. Ministerstvo průmyslu a obchodu ČR. Prosinec 2014. Dostupné z: www.mpo.cz/dokument158012.html.

[20] Waste Heat Recovery: Technology and Opportunities in U.S. Industry. Industrial Technologies Program. U.S. Department of Energy. Dostupné z: http://www1.eere.energy.gov/manufacturing/ intensiveprocesses/pdfs/waste_heat_recovery.pdf.

[21] Hasal, P., I. Schreiber, D. Šnita et al. Chemické inženýrství I. 2. vyd. Praha: Vysoká škola chemicko-technologická v Praze, 2007. ISBN 978-80-7080-002-7.

[22] Global desalination capacity growing substantially, finds study [online]. [cit. 11. únor 2015]. Dostupné z: www.waterworld.com/articles/2013/10/global-desalination-capacity-tops-80-million-cubic-meters-per-day.html.

[23] Khawaji, A.D., I.K. Kutubkhanah, and J. Wie. Advances in seawater desalination technologies Desalination [online]. 2008, vol. 221, n. 1-3, European Desalination Society and Center for Research and Technology Hellas (CERTH), Sani Resort 22 -25 April 2007, Halkidiki, Greece European Desalination Society and Center for Research and Technology Hellas (CERTH). Sani Resort p. 47-69. ISSN 0011-9164. Dostupné z: doi:10.1016/j.desal.2007. 01. 067.

[24] NG, K.CH., K. Thu, S.J. Oh, L. Ang, M.W. Shahzad, and A.B. Ismail. Recent developments in thermally-driven seawater desalination: Energy efficiency improvement by hybridization of the MED and AD cycles. Desalination [online]. 2015, vol. 356, State-of-the-Art Reviews in Desalination, p. 255 270. ISSN 0011-9164. Dostupné z: doi:10.1016/j.desal.2014. 10. 025.

[25] Van Der Bruggen, B. and C. Vandecasteele. Distillation vs. membrane filtration: overview of process evolutions in seawater desalination. Desalination [online]. 2002, vol. 143, n. 3, p. 207-218. ISSN 0011-9164. Dostupné Z: doi:10.1016/S0011-9164(02)00259-X.

[26] El-Dessouky, H., H.I. Shaban, and H. Al-Ramadan. Steady-state analysis of multi-stage flash desalination process. Desalination [online]. 1995, vol. 103, n. 3, p. 271-287. ISSN 0011-9164. Dostupné z: doi:10.1016/0011-9164(95)00080-1.

[27] Hájek, Z. Výzkum zařizení pro úpravu mořské vody a dalši aplikace. Brno: Vysoké učení technické v Brně, Fakulta strojního inženýrství, 2014. 148 s. Vedoucí dizertační práce doc. Ing. Zdeněk Jegla, Ph.D.

[28] Průvodcevýrobouavyužitímbioplynu[online].CZBiom-Českésdruženíprobiomasu.Praha:2009.Dostupné z: http://www.mpo-efekt.cz/upload/7799f3fd595eeeelfa66875530f33e8a/Pruvodce_vyrobou _vyuzitim_bioplynu_2.pdf

[29] Gutiérrez, G., J.M. Benito, J. Coca, and C. Pazos. Vacuum Evaporation of Waste Oil-in-Wate Emulsions from a Copper Metalworking Industry. Industrial \& Engineering Chemistry Research [online] 2009, vol. 48, n. 4, p. 2100-2106. ISSN 0888-5885. Dostupné z: doi:10.1021/ie801054d.

\section{[30] Evaluation of Hadwaco MVR Evaporator. DIANE Publishing, March 2002. ISBN 978-1-4223-3100-2.}

[31] Mao, W., H. Ma, and B. Wang. Performance of batch vacuum distillation process with promoter on coke-plant wastewater treatment. Chemical Engineering Journal [online]. 2010, vol. 160, n. 1, p. 232 238. ISSN 1385-8947. Dostupné z: doi:10.1016/j.cej.2010. 03. 053.

[32] Tóth, A.J., F. Gergely, and P. Mizsey. Physicochemical treatment of pharmaceutical process wastewater: Distillation and membrane processes. Periodica Polytechnica: Chemical Engineering [online]. 2011, vol. 55, n. 2, p. 59-67. ISSN 0324-5853. Dostupné z: doi:10.3311/pp.ch.2011-2. 03

[33] Chiumenti, A., F. Da Borso, R. Chiumenti, F. Teri, and P. Segantin. Treatment of digestate from a co-digestion biogas plant by means of vacuum evaporation: Tests for process optimization and environmental sustainability. Waste Management [online]. 2013, vol. 33, n. 6, p. 1339-1344. ISSN 0956 053X. Dostupné z: doi:10.1016/j.wasman.2013. 02. 023

\section{Autoři}

Ing. Mgr. Marek Vondra

凶vondra@upei.fme.vutbr.cz

Ing. Petr Bobák, Ph.D.

凶bobak@fme.vutbr.cz

Ing. Vítězslav Máša, Ph.D.

凶masa@fme.vutbr.cz

Vysoké učení technické v Brně, Fakulta strojního inženýrství, NETME Centre \& Ústav procesního inženýrství

Přispěvek prošel lektorským řízením.

\section{WASTE HEAT UTILIZATION FOR INDUSTRIAL WASTEWATER TREATMENT}

\section{VONDRA, Marek; BOBAK, Petr; MASA, Vitezslav}

Brno University of Technology, Faculty of Mechanical Engineering, NETME Centre \& Department of Process Engineering

Key words: wastewater - waste heat - industry -

evaporation - thickening - multi-stage flash distillation

This paper deals with an industrial wastewater treatment utilizing waste heat from related industrial processes. More than 280 mil. $\mathrm{m}^{3}$ of wastewater is produced yearly and much more is consumed by the industrial sector in the Czech Republic. It is also a significant consumer of different energy sources. Unfortunately, more than 17.5 TWh of thermal energy leaves annually from the industry without any form of utilization. This study proposes a possible solution, which is capable of reduction of industrial wastewater on one side and effective utilization of industrial excess heat on the other. For this purpose, well-proven desalination technologies (Multi-effect distillation and multi-stage flash distillation) are briefly introduced and their typical operational parameters are discussed. Simple design and reliable operation are one of the main advantages of these methods, while low specific energy consumption would be another plus, if the industrial waste heat could be utilized. Wide range of different wastewater could be treated by the means of evaporation, as it is presented in many studies. Interesting experimental results from these studies on metalworking, coke, pharmaceutical or biological wastewater treatment are further discussed. Finally, the potential of wastewater treatment by the means of multi-stage flash distillation in the Czech Republic is thoroughly considered and several calculations are done. The results indicate huge potential of this approach. With only $0.94 \%$ of the overall industrial waste heat utilized, the evaporation technology is capable of decreasing water consumption in the industry by 8.5 mil. $\mathrm{m}^{3}$ per year. 